\title{
Effect of caffeinated energy drinks on the structure of hippocampal cornu ammonis 1 and dentate gyrus of adult male albino rats
}

\author{
Sherif A. Kamar, Hany W. Abdel Malak, Shereen Adel Saad \\ Department of Anatomy, Faculty of Medicine, Ain Shams University, Cairo, Egypt
}

\begin{abstract}
Energy drinks are available worldwide and frequently consumed to increase energy level and compensate lack of sleep. Energy drinks consumers aim to improve their cognitive functions. Red Bull is the most popular energy drink consumed in Egypt. However, the link between the impact of energy drinks on the structure of hippocampal cornu ammonis 1 (CA1) and dentate gyrus (DG), a highly vulnerable brain regions to various insults, has not yet documented. To study the effect of energy drinks on structure of hippocampal CA1 and DG of adult male albino rats. Twenty one adult male albino rats were divided into three groups; group I control group, groups II and III received Red Bull, with a dose of $3.75 \mathrm{ml} / \mathrm{kg} / \mathrm{day}$ orally using gastric tube for four and eight consecutive weeks respectively. At the end of the experiment, brains were dissected and hippocampal specimens were processed for histopathological and immunohistochemical studies. Histopathological examination of hippocampal sections in group II revealed vacuoles, decrease thickness of pyramidal cell layer with irregular dark or ghost nuclei. However, changes were more severe in group III with cracks in pyramidal cell layer, massive vacuolation and signet ring cells. Moreover, star shaped astrocytes and glial fibrillary acidic protein immuno-reactivity were more abundant in group III than in group II. Caffeinated energy drinks produced neurodegenerative changes and reactive astrocytosis in hippocampal CA1 and DG of adult male albino rats. These changes were duration-dependent being more severe in longer duration of intake.
\end{abstract}

Key words: Energy drinks, Hippocampus, Cornu ammonis, Dentate gyrus, Energy drinks

Received June 1, 2020; Revised June 24, 2020; Accepted June 28, 2020

\section{Introduction}

Energy drinks are available worldwide. The active ingredients that are found in most energy drinks (caffeine, taurine, glucose, and many vitamins), provide the body with great deal of mental and physical energy [1]. These energy drinks are aggressively marketed to consumers with attrac-

\footnotetext{
Corresponding author:

Sherif A. Kamar (iD)

Department of Anatomy, Faculty of Medicine, Ain Shams University, Cairo 11566, Egypt

E-mail:Sherif_Kamar@med.asu.edu.eg
}

tive names, to express the strength, speed, and power as Red Bull (GmbH, Fuschl am See, Austria), Boom Boom (Tempire Group, Fort Worth, TX, USA), and Power Horse (PH USA, Inc., San Francisco, CA, USA) [2]. Red Bull is the most popular energy drink consumed in Egypt [3].

These drinks are frequently consumed by athletes, teenagers, and college students in order to increase their energy level and compensate for the lack of sleep. They may also improve mood, physical performance and reduce mental fatigue $[4,5]$.

However, the International Society of Sports Nutrition recently announced concerns regarding safety and efficacy of energy drink [6]. In addition, an alarming number of cardiovascular side effects including arrhythmia, cardiac arrest 
up to even sudden death were reported because of energy drinks' consumption [7-10].

Some studies also reported many harmful effects of energy drinks on the kidney, liver and heart [11, 12]. Other studies demonstrated a notable increase in total protein, triglyceride, high density lipoproteins, low density lipoproteins, cholesterol, and glucose with a decrease in alanine transaminase, aspartate transaminas, creatinine, uric acid and albumin in energy drinks' administrated rats [13].

Moreover, many authors declared that caffeinated energy drinks had adverse effects on the brain such as anxiety, stress, hyper movement, headache, and fatigue [14, 15]. Others declared more adverse effects including depression, sleep disturbance and irritability $[16,17]$.

Being a part of the limbic system, the hippocampus plays an important role in learning, emotions in addition to consolidation of recent short-term memory into long-term memory [18]. The limbic system consists of interconnected cortical and subcortical arrangements responsible for connecting visceral states and emotions to cognition and behavior [19].

Most energy drinks consumers aim to improve their higher cognitive functions as memory. However, the link between the impact of energy drinks as Red Bull on memory and hippocampal structure has not yet been documented [20].

The hippocampal cornu ammonis 1 (CA1) is considered the most sensitive zone that is vulnerable to various insults [21]. In addition, it is one of three brain regions that are most susceptible to oxidative stress and the first to undergo decline in its function [22]. The dentate gyrus (DG), is another vulnerable brain tissue that contains adult neuronal stem cells which are responsible for adult hippocampal neurogenesis [23].

Hence, it became the aim of the present work to study the effect of energy drinks as Red Bull on the structure CA1 and DG of the hippocampus of adult male albino rats.

\section{Materials and Methods}

\section{Animals}

Twenty-one adult male albino rats, 3-6 month old and 150-200 g in weight, were obtained from the animal house of The Bilharzial Research Unit, Faculty of medicine Ain Shams University, Cairo, Egypt. The animals were housed in conventional wire-mesh cages in a room temperature regulated at $21^{\circ} \mathrm{C} \pm 10^{\circ} \mathrm{C}$, humidity $45 \%$ to $50 \%$, and light/dark cycles (/12 hours). The animals were fed on standard rat diet and allowed free water access. Animals were allowed to ac- climatize to experimental conditions by housing them for 10 days prior to experiment.

\section{Drugs}

Red Bull energy drink was purchased from the local Egyptian market.

\section{Experimental protocol}

Experiment was carried according to the guide of the Committee of the Animal Research Ethics (CARE) at Faculty of Medicine, Ain Shams University. Twenty-one adult male albino rats were equally and randomly divided into three groups:

Group I (Control group): included seven rats that were left untreated.

Group II (Short-term Red Bull group): included seven rats which received Red Bull at a dose of $3.75 \mathrm{ml} / \mathrm{kg} /$ day orally using gastric tube for four consecutive weeks [24]. This dose $(3.75 \mathrm{ml})$ contains $(1.13 \mathrm{mg})$ of caffeine.

Group III (Long-term Red Bull group): included seven rats which received Red Bull at a dose of $3.75 \mathrm{ml} / \mathrm{kg} /$ day orally using gastric tube for eight consecutive weeks [24]. This dose $(3.75 \mathrm{ml})$ contains $(1.13 \mathrm{mg})$ of caffeine.

\section{Methods}

At the end of the experiment, rats were anaesthetized with ether inhalation. Animals were decapitated. The scalp was removed, and the nose was cut off, an opening in the lambdoid suture was done for rapid fixation of the brain. The heads were immersed in Bouin's solution for 2 days. The bone overlying the cerebral hemispheres was removed. The brains were dissected carefully and immersed in the Bouin's solution for 10 days till hardening occurred [25]. The brains were hemi-sectioned by sagittal incision passing through the corpus callosum.

\section{Histological studies}

The brain hemispheres were processed for paraffin blocks. Serial parasagittal sections were done. The sections were stained with hematoxylin and eosin [26]. Other specimens $1 \mathrm{~mm}^{3}$ were immediately fixed in $4 \%$ glutaraldehyde and processed for semithin sections. Sections were stained with Toluidine blue [27]. The sections were examined with an Olympus light microscope (CX31) equipped with digital camera in Anatomy department and were photographed.

GFAP immunohistochemistry was done to demonstrate 
the astrocytes. Sections were Deparaffinated, hydrated and incubated in blocking solution TBT [Tris Base Saline (TBS), $0.5 \mathrm{M} \mathrm{pH} 7.4$ containing 3\% (w/v) bovine serum albumin and $0.05 \%(\mathrm{v} / \mathrm{v})$ Triton X-100]. Sections were incubated overnight at $4^{\circ} \mathrm{C}$ in a humidified chamber with the anti- glial fibrillary acidic protein (GFAP) mouse monoclonal antibody at a 1:50 dilution. Slides were washed for 5 minutes in TBS. Immunodetection was performed using biotinylated anti-mouse immunoglobulins then incubation with 3,3 diaminobenzidine chromogen (DAKO) in hydrogen peroxide for 5-10 minutes (brown staining). The sections were lightly counterstained with Mayer's hematoxylin, dehydrated and mounted [28].

\section{Morphometric study and statistical analysis}

The measurements were done using image analyzer (Image J program [University of Wisconsin, Madison, WI, USA] and TS view program [CX31, Olympus, Japan]) in Anatomy department - Ain Shams University as follow:

1) Thickness of pyramidal cell layer was measured using digital micrographs taken by an Olympus CX31 microscope equipped with digital camera. Pixels were calibrated for actual measurements in micrometer using stage micrometer for the objective lens of $40 x$.

2) Cell count was done by using point selection at the objective lens of $40 \times$.

3) Mean area percentage of GFAP immunoreactivity was done after image splitting. Images were converted into RGB stacks then red stack was adjusted to threshold to

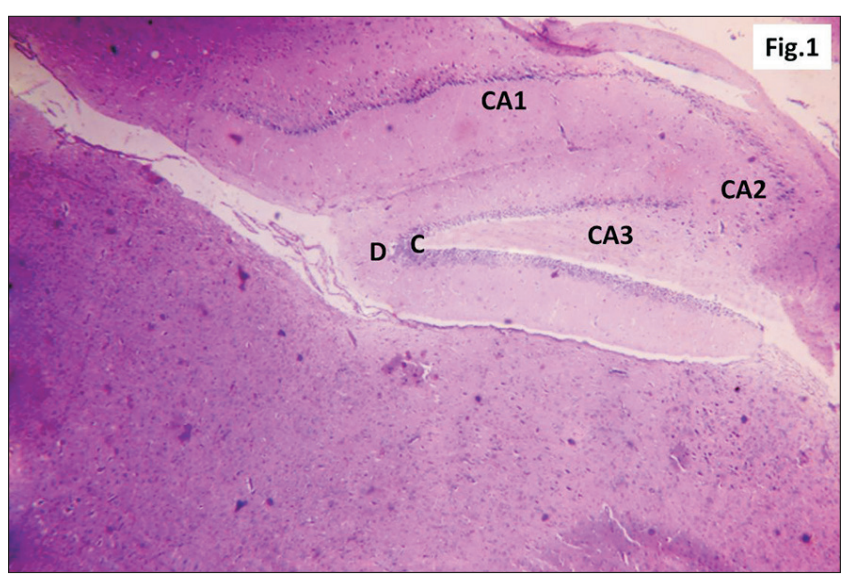

Fig. 1. A photomicrograph of parasagittal section of hippocampus of control rats showing its 3 regions; CA1, CA2, and CA3 (H\&E, $\times 100)$. The D appeared V-shaped, with its C. C, crest; CA1, cornu ammonis 1; CA2, cornu ammonis 2; CA3, cornu ammonis 3; D, dentate gyrus. mark it with a binary mask. Then the percent area in relation to the field was calculated at the objective lens of $40 \times$. The area percentage was measured in five fields, from five serial sections, from five animals, from each group [29].

The data were recorded, entered, and processed on a compatible computer using GraphPad Prism Program (version 5.0; GraphPad Software, San Diego, CA, USA) for using IBM SPSS Statistics for Windows, Version 25.0 (IBM Co., Armonk, NY, USA).

One-way analysis of variance (ANOVA) was employed to compare means between groups. All the data were represented as mean \pm standard error of mean for each subgroup.

The level $P \leq 0.05$ was considered the cut-off value for significance. Results were considered statistically significant when $P$-value $\leq 0.05$ and highly significant when $P$ value $\leq 0.001$ [30]. The $P$-value value was corrected according to Bonferroni procedure by dividing the $\alpha$ value by the number of the compared groups $(\mathrm{m})(\alpha / \mathrm{m})$ [31]. Data were represented in tables and bar charts.

\section{Results}

\section{Histological results}

\section{Group I (control group)}

Examination of the parasagittal sections of hippocampi of the control group of rats showed that the hippocampal

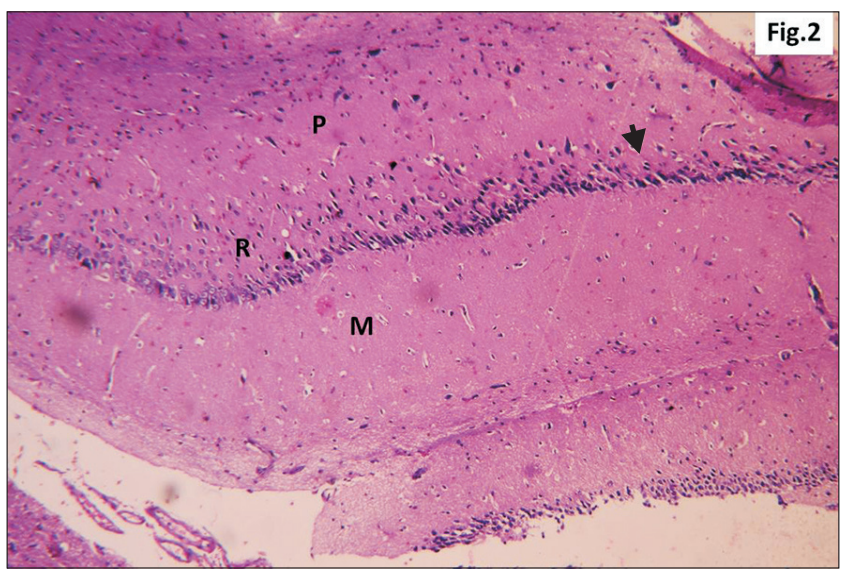

Fig. 2. A photomicrograph of a parasagittal section of control hippocampus showing CA1, with three layers of cells, P, R, and M (H\&E, $\times 200)$. P layer is seen as a clear narrow zone with widely spaced small deeply stained oligodendroglia cells (arrowhead). R cell layer contains closely packed cells (arrow). The M layer contains widely spaced cells. CA1, cornu ammonis 1; M, molecular; P, polymorphic; R, pyramidal. 


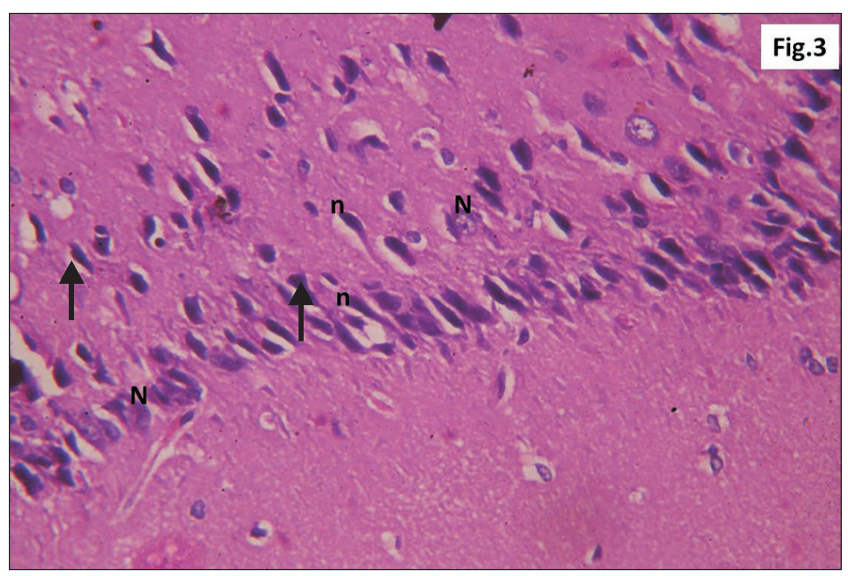

Fig. 3. A photomicrograph of a parasagittal section of control hippocampus showing $\mathrm{R}$ cells in CA1, R cells appear large closely packed triangular neurons (arrow) (H\&E, $\times 400)$. Some with $\mathrm{N}$ and others with $\mathrm{n}$. CA1, cornu ammonis 1 ; $\mathrm{n}$, dense elongated nuclei; $\mathrm{N}$, vesicular nuclei; R, pyramidal.

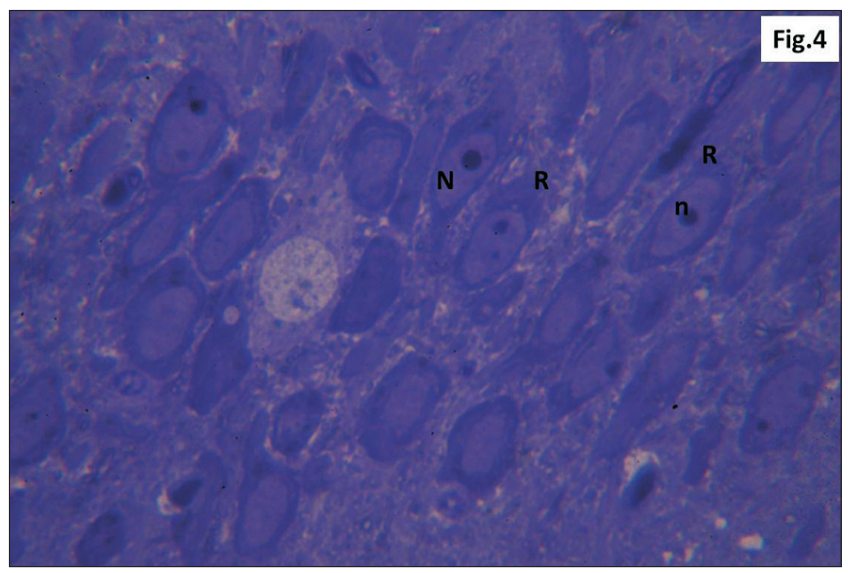

Fig. 4. Semithin section of control hippocampal CA1 showing dark closely packed large, triangular $\mathrm{R}$ cells with vesicular $\mathrm{N}$ and prominent $\mathrm{n}$ (Toluidine blue, $\times 1,000)$. CA1, cornu ammonis 1 ; n, nucleoli; N, nuclei; $\mathrm{R}$, pyramidal.

formation was formed of hippocampus proper and DG. Hippocampus proper was further subdivided into three regions which are (CA1, CA2, and CA3). The DG appeared Vshaped, with crest and two limbs curved around CA3 (Fig. 1).

CA1 appeared to be composed of three distinctive layers; polymorphic, pyramidal, and molecular. The Polymorphic layer was a clear narrow outer zone that was relatively acellular and revealed widely spaced small deeply stained oligodendroglia cells (Fig. 2). The Pyramidal cell layer, deep to the polymorphic layer, was the main cell layer containing the major neuronal cells in CA region and had closely packed deeply stained large cells (Fig. 2). Pyramidal cells appeared

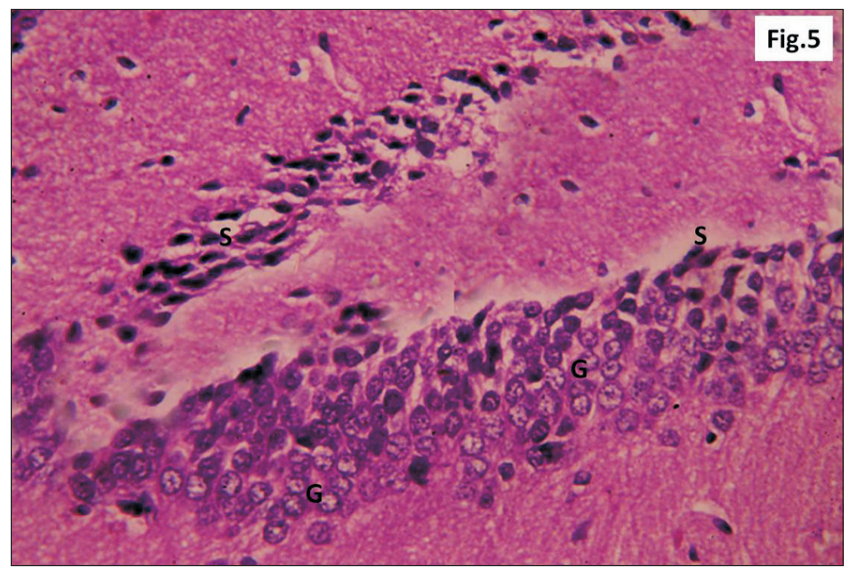

Fig. 5. A photomicrograph of a parasagittal section of control hippocampus showing DG with packed granule layer $(\mathrm{H} \& \mathrm{E}, \times 100)$. The $\mathrm{G}$ appear rounded to oval with large vesicular nuclei. $S$ are present. DG, dentate gyrus; G, granule dark cells; S, deeply stained stem cells .

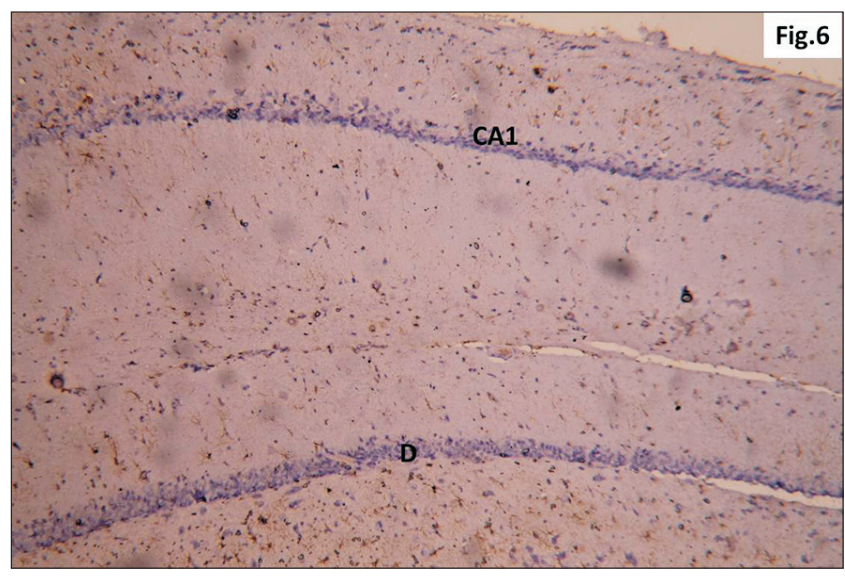

Fig. 6. A photomicrograph of a GFAP immunostaining of hippocampus of adult male control rat showing the normal distribution of apparently few brownish star shaped astrocytes in CA1 and D (GFAP, $\times 200$ ). CA1, cornu ammonis 1 ; DG, dentate gyrus; GFAP, glial fibrillary acidic protein.

triangular, some of them had vesicular nuclei and others had dense elongated nuclei (Fig. 3). The molecular layer was the most inner layer, adjacent to suprapyramidal limb of the DG. It contained widely spaced cells (Fig. 2).

Examination of semithin sections revealed triangular deeply stained pyramidal neurons with vesicular nuclei and prominent nucleoli (Fig. 4). DG revealed packed granule cell layer whose granule cells appeared rounded to oval with large vesicular nuclei in addition to deeply stained stem cells (Fig. 5).

In GFAP stained sections, normal distribution of apparently few brownish star shaped astrocytes were seen in CA1 


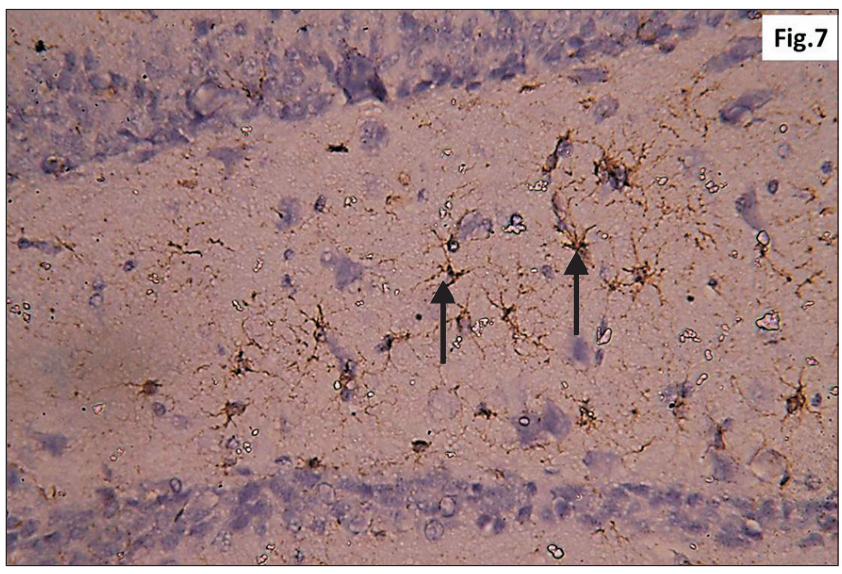

Fig. 7. Higher magnification of a GFAP immunostaining of hippocampus of adult male control rat showing the normal distribution of brown star shaped astrocytes (arrow) within the junctional zone between molecular layers of CA1 and DG (GFAP, ×400). CA1, cornu ammonis 1; DG, dentate gyrus; GFAP, glial fibrillary acidic protein.

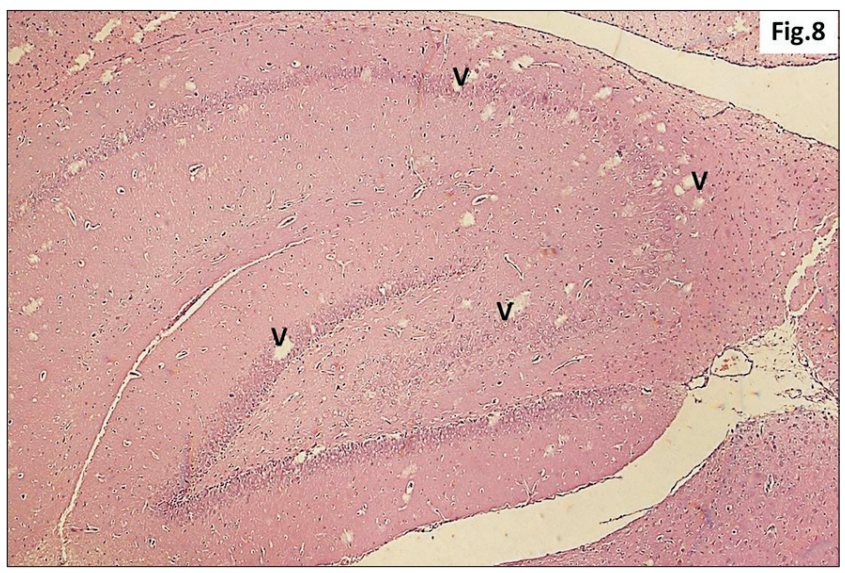

Fig. 8. A photomicrograph of a parasagittal section of hippocampus from group II showing apparent preservation of general architecture with diffuse $\mathrm{v}$ in all its regions $(\mathrm{H} \& \mathrm{E}, \times 100)$. $\mathrm{v}$, vacuolation.

and DG (Fig. 6). GFAP also revealed the normal distribution of brown star shaped astrocytes within the junctional zone between the molecular layers of CA1 and DG (Fig. 7).

\section{Group II (Short-term Red Bull group)}

Examination of the hippocampus of short-term Red Bull group showed preservation of the general architecture of the hippocampus. However, diffuse vacuolations were observed in all hippocampal regions (Fig. 8). An apparent decrease in the thickness of principal neuronal layer in CA1 was observed (Fig. 9). Neurons with dark nuclei were seen with increased pericellular space (Fig. 9). Higher magnification

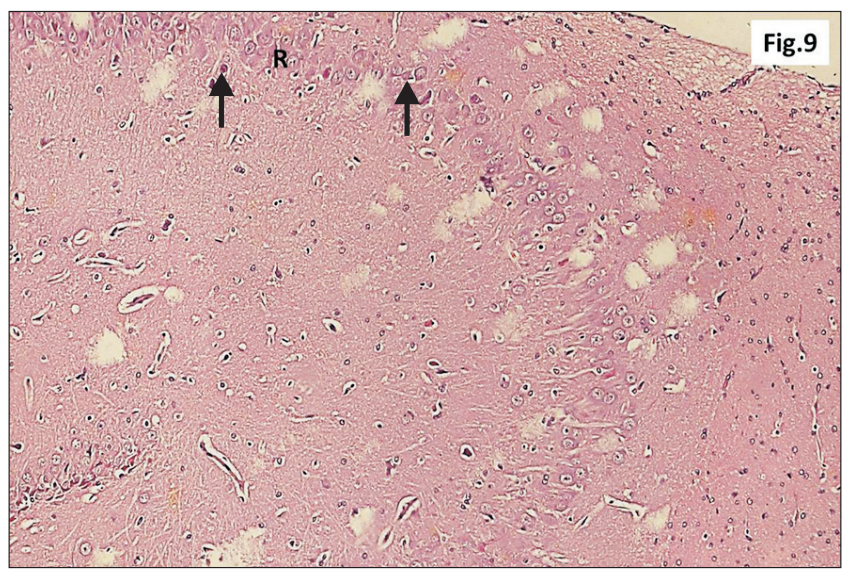

Fig. 9. Higher magnification of a parasagittal section of hippocampus from group II showing an apparent decreased thickness of principal neuronal cell layer of CA1 (R) $(\mathrm{H} \& \mathrm{E}, \times 200)$. Note some neurons with dark nuclei and wide pericellular space (arrow). CA1, cornu ammonis 1; R, pyramidal cell layer.

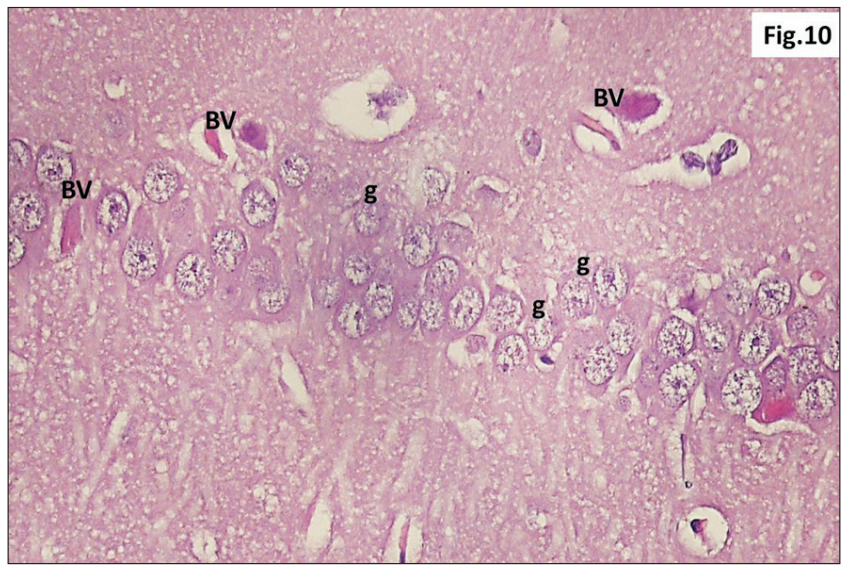

Fig. 10. Higher magnification of a parasagittal section of hippocampus from group II showing many g within CA1 (H\&E, $\times 400)$. Many congested BV are also observed. BV, blood vessels; CA1, cornu ammonis 1; g, ghost neurons.

revealed some ghost neurons in CA1, and many congested blood vessels (Fig. 10). Dentate gyrus showed lightly stained ghost cells with some darkly stained cells. Increased number of stem cells in the crest of DG was also noticed (Fig. 11).

Semithin sections showed diffuse vacuolations in the DG, lightly stained cells with vesicular nuclei and other dark cells with dark irregular nuclei and some shrunken ghost cells (Fig. 12).

In GFAP stained sections, an apparent increase in brownish positive immune reaction was observed in all hippocampal layers (Fig. 13), together with increased distribution of brownish star shaped astrocytes in the junctional zone 


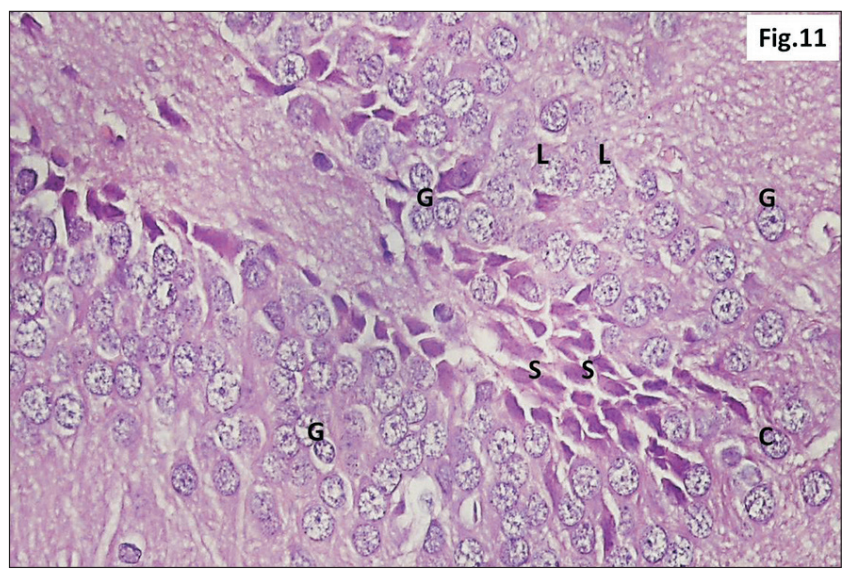

Fig. 11. A photomicrograph of a parasagittal section of hippocampus from group II showing $L$ and some $G$ within the DG $(H \& E, \times 400)$. An increased number of $S$ were observed in the C of DG. C, crest; DG, dentate gyrus; G, darkly stained cells; L, lightly stained ghost cells; S, stem cells.

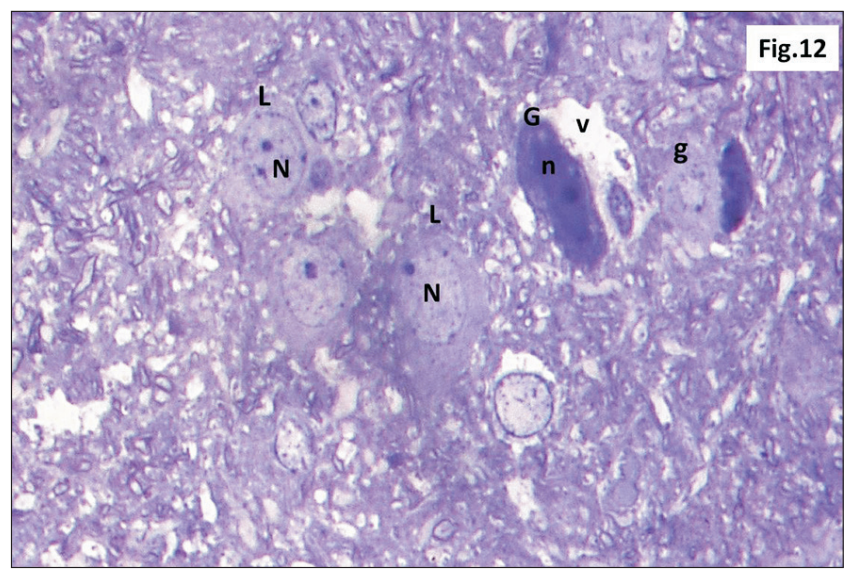

Fig. 12. Semithin sections of hippocampus from group II showing diffuse $v$ within the DG. $L$ with $\mathrm{N}$ and other $\mathrm{G}$ with $\mathrm{n}$ are seen. Some shrunken $g$ are also observed (Toluidine blue, $\times 1,000$ ). DG, dentate gyrus; g, ghost cells; G, dark cells; L, lightly stained cells; n, dark irregular nuclei; $\mathrm{N}$, vesicular nuclei; v, vacuolations.

between molecular layers of CA1 and dentate (Fig. 14).

\section{Group III (Long term Red Bull group)}

Examination of the hippocampus of long-term Red Bull group showed preservation of the general architecture of the hippocampus (Fig. 15). An obvious decrease in thickness of principle neuron cell layers was observed in all hippocampal regions (Fig. 15). Most of CA1 neurons appeared with dark irregular nuclei and signet ring cells with pyknotic peripheral nuclei (Fig. 16), in addition to diffuse vacuolations within the pyramidal cell layer (Fig. 16). DG showed an appar-

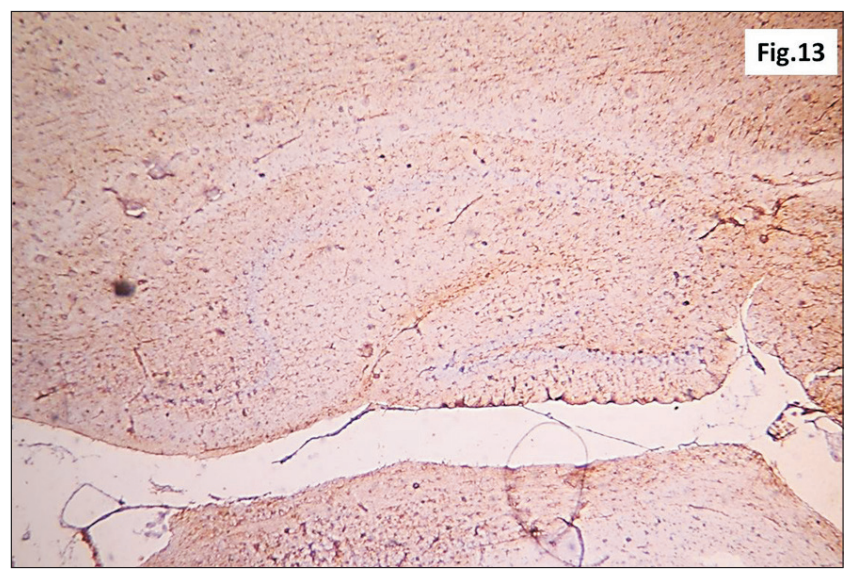

Fig. 13. A photomicrograph of a GFAP immunostaining of hippocampus from group II showing an apparent increase in the brownish positive immuno-reaction in all layers (GFAP, $\times 200)$. GFAP, glial fibrillary acidic protein.

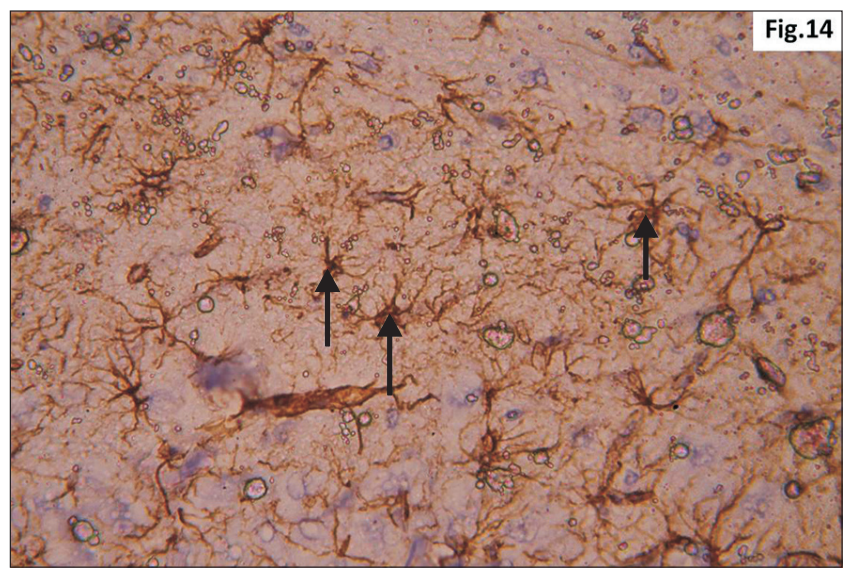

Fig. 14. Higher magnification of a GFAP immunostaining of hippocampus from group II showing increased distribution of brownish star shaped astrocytes (arrow) in the junctional zone between molecular layers of CA1 and DG (GFAP, ×400). CA1, cornu ammonis 1; DG, dentate gyrus; GFAP, glial fibrillary acidic protein.

ent thinning of the granule cell layer, with widespread cracks (Fig. 17). Most of the cells appeared with dark pyknotic nuclei and some signet ring neurons (Fig. 18). Intense vacuolations (Fig. 17) and cracks (Figs. 17 and 18) in-between the cells were observed. Marked increase in the number of stem cells in the crest of DG was noted (Fig. 18). Loss of compact organization of the granular neurons of the DG with dark pyknotic nuclei and ghost cells were seen in some areas (Fig. 19).

Semithin sections showed lightly stained neurons with pale nuclei and others with dark irregular nuclei. Multiple diffuse small vacuoles were also noticed (Fig. 20).

In GFAP stained sections, an intense increase in the 


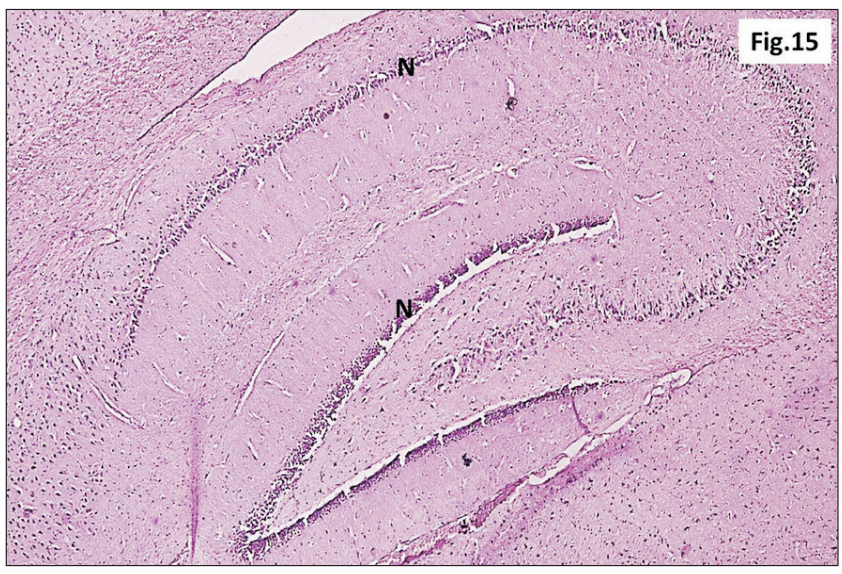

Fig. 15. A photomicrograph of a parasagittal section of hippocampus from group III showing preservation of the general architecture of the hippocampus. However, an apparent marked decrease in thickness of $\mathrm{N}$ was observed in all regions $(\mathrm{H} \& \mathrm{E}, \times 100)$. $\mathrm{N}$, principal neuronal cell layers.

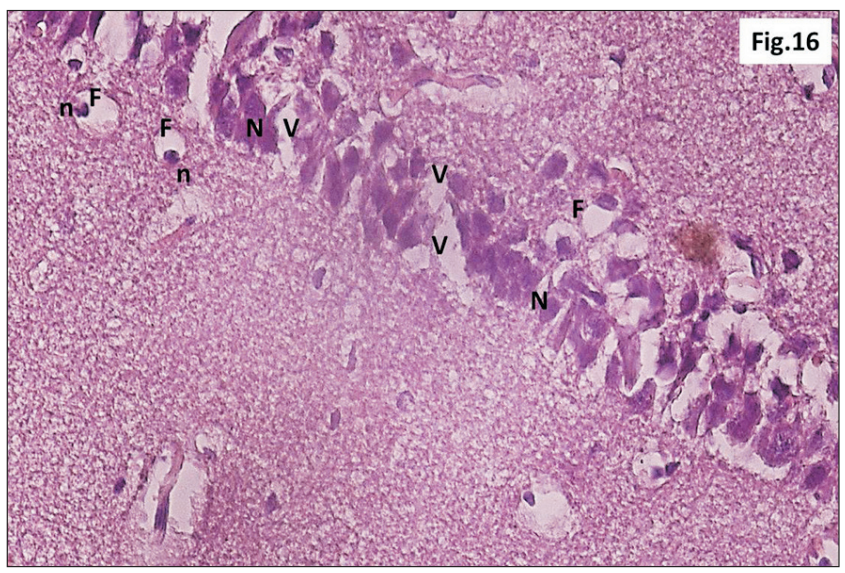

Fig. 16. Higher magnification of a parasagittal section of hippocampus from group III showing that most of CA1 neurons have $\mathrm{N}$ (H\&E, $\times 400) . F$ are observed with $\mathrm{n}$. Diffuse $\mathrm{V}$ within the $\mathrm{R}$ cell layer is also seen. CA1, cornu ammonis 1; F, signet ring cells; n, pyknotic peripheral nuclei; N, dark irregular nuclei; R, pyramidal, V, vacuolation.

brownish positive immune reaction in all hippocampal regions was observed (Fig. 21). Also, wide distribution of large dark brown star shaped astrocytes with multiple thick processes was seen in the junctional zone between molecular layers of CA1 and DG (Fig. 22).

\section{Statistical results}

As shown in Fig. 23, Pyramidal cells' thickness was highly significant reduced in one-month group and two-months group respectively compared to the control group $\left({ }^{\star \star} P<0.01\right.$,

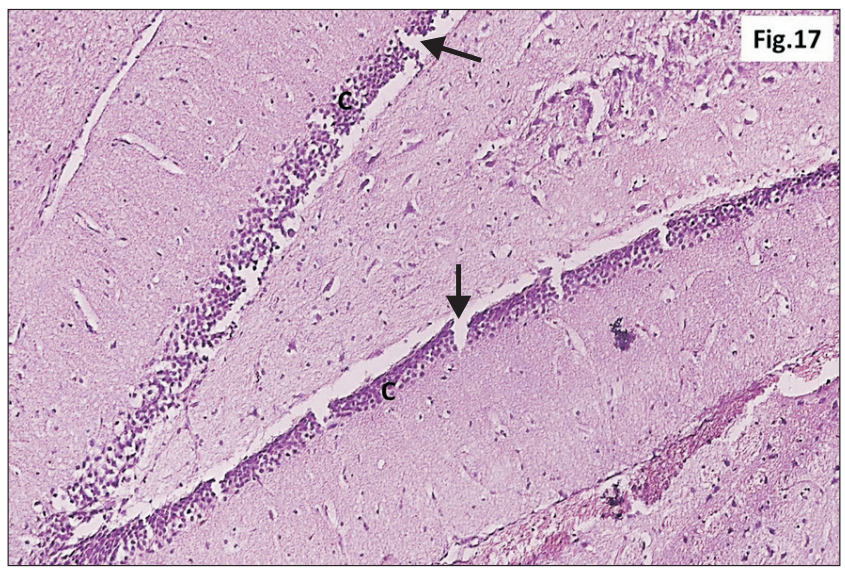

Fig. 17. A photomicrograph of a parasagittal section of hippocampus from group III showing an apparent thinning of C of DG with widespread cracks (arrow) within the layer $(\mathrm{H} \& \mathrm{E}, \times 200)$. C, granular cell layer; DG, dentate gyrus.

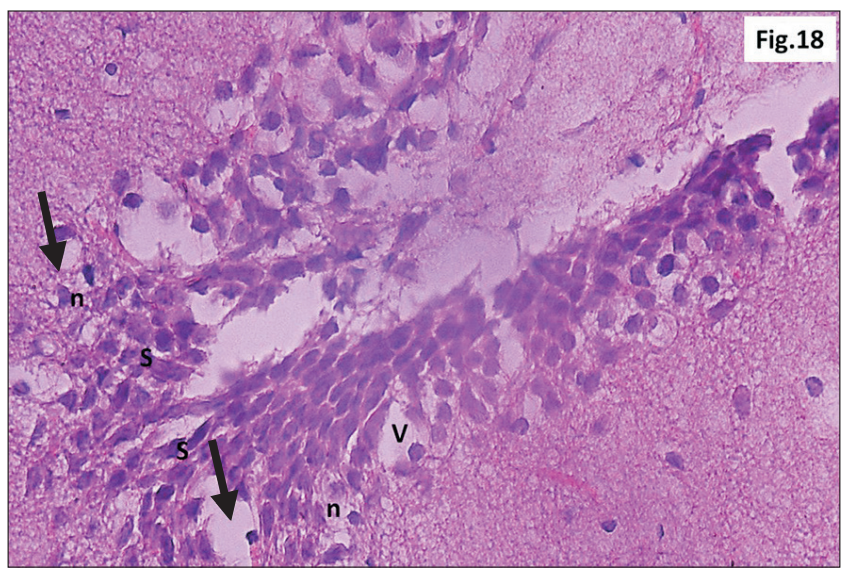

Fig. 18. A photomicrograph of a parasagittal section of hippocampus from group III showing granular neurons of the DG with n, and signet ring neurons (arrow) (H\&E, $\times 400)$. Intense $\mathrm{V}$ and $\mathrm{C}$ in between the granular cells are observed. Marked increase in the number of $S$ cells in the crest of DG are also seen. C, cracks; DG, dentate gyrus; n, dark pyknotic nuclei; S, stem; V, vacuolation.

$\left.{ }^{* *} P<0.001\right)$, and significant reduction was observed in twomonths group compared to one-month group $\left({ }^{*} P<0.05\right)$.

Also, as shown in Fig. 24, pyramidal cells' number were highly significant reduced in one-month group and twomonths group respectively compared to the control group $\left.{ }^{* *} P<0.01,{ }^{* *} P<0.001\right)$, with more significant decreased in number in the two-months group than one-month group $\left({ }^{*} P<0.05\right)$.

In addition, as shown in Fig. 25, the percentage area of GFAP immuno-reactivity was highly significant increased in one-month group and two-months group respectively com- 


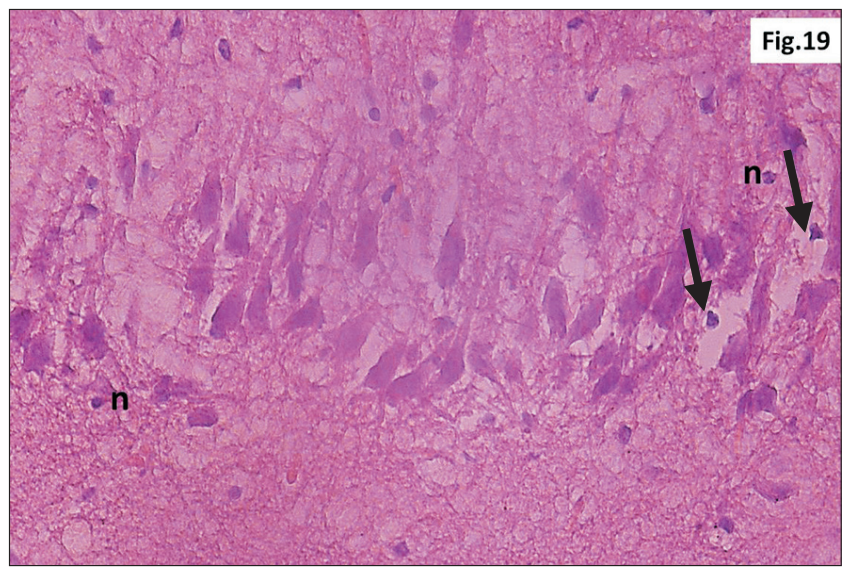

Fig. 19. A photomicrograph of a parasagittal section of hippocampus from group III showing loss of compact organization of the granular neurons of the DG with $\mathrm{n}$, and ghost cells (arrow) (H\&E, ×400). DG, dentate gyrus; $\mathrm{n}$, dark pyknotic nuclei.

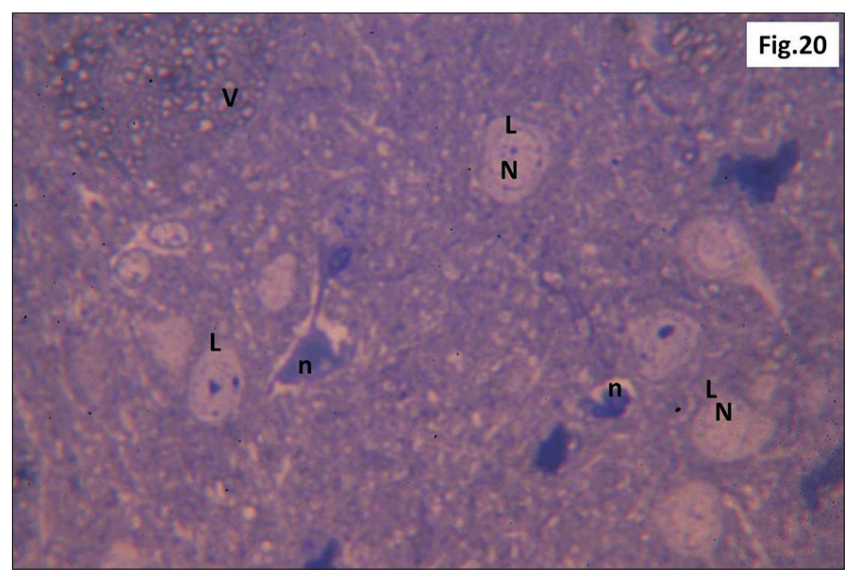

Fig. 20. Semithin sections of hippocampus from group III showing L with $\mathrm{N} \&$ other neurons with $\mathrm{n}$ are observed. Multiple diffuse small V are observed (Toluidine blue, $\times 1,000$ ). L, lightly stained neurons; $\mathrm{n}$, dark irregular nuclei; N, pale nuclei; V, vacuoles.

pared to the control group $\left.{ }^{* * *} P<0.001\right)$, with more significant increase in the two-months group than in one-month $\left({ }^{\# \# \#} P<0.001\right)$.

\section{Discussion}

Hippocampal CA1 is one of three brain regions considered most susceptible to oxidative stress and various insults leading to rapid decline in its function [21,22]. Also, the DG, is another vulnerable brain tissue that contains adult neuronal stem cells which are responsible for adult hippocampal neurogenesis [23]. Caffeinated energy drinks are available

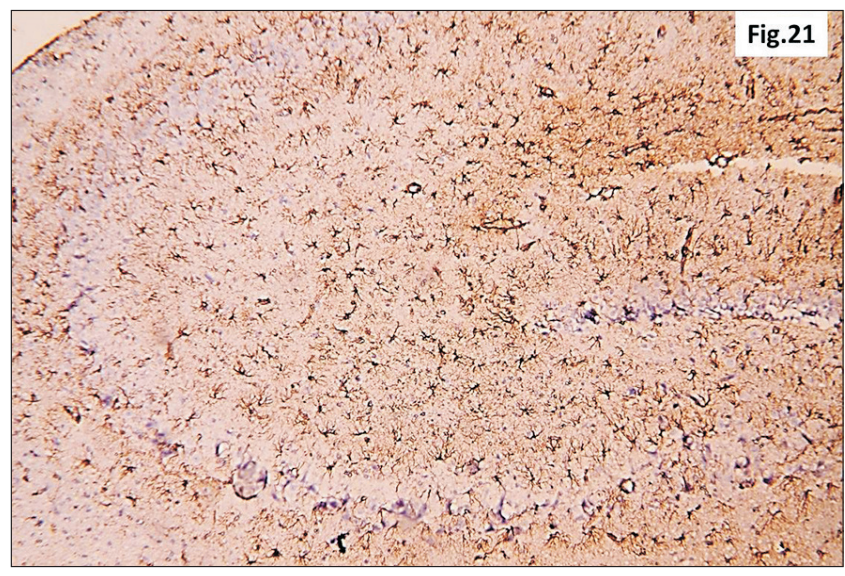

Fig. 21. A photomicrograph of a GFAP immunostaining of hippocampus from group III showing an apparent intense increase in the brownish positive immuno-reaction in all regions (GFAP, $\times 200$ ). GFAP, glial fibrillary acidic protein.

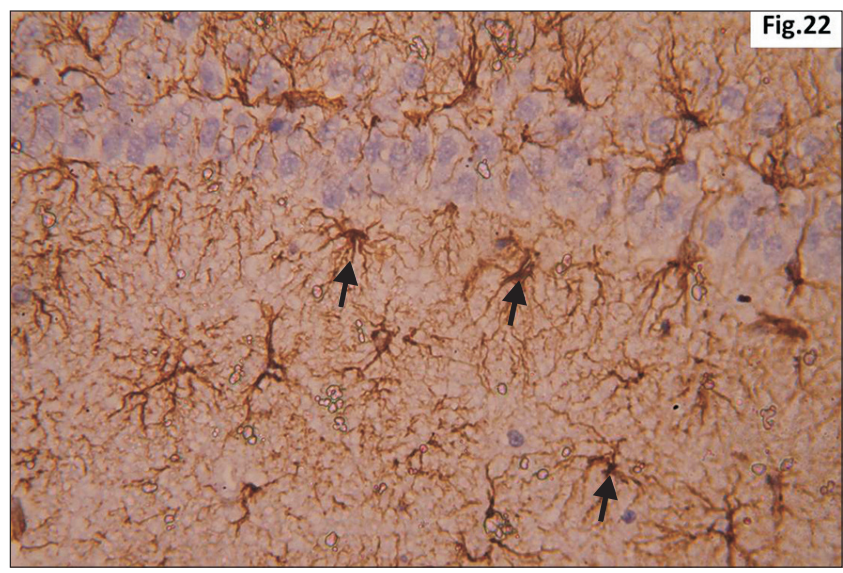

Fig. 22. Higher magnification of a GFAP immunostaining of hippocampus from group III showing wide distribution of large dark brown star shaped astrocytes with multiple thick processes (arrow) in the junctional zone between molecular layers of CA1 and DG (GFAP, $\times 400$ ). CA1, cornu ammonis 1 ; DG, dentate gyrus; GFAP, glial fibrillary acidic protein.

worldwide and are frequently used to improve mood, physical performance and reduce mental fatigue $[4,5]$. However, they have many nervous side effects as anxiety, headache, fatigue $[14,15]$, depression and sleep disturbance $[16,17]$. So, the aim of the present work was to study the effect of energy drinks as Red Bull on the structure of CA1 and DG of the hippocampus of adult male albino rats.

The present study revealed that, after one month of Red Bull administration, diffuse vacuolation was observed both in CA1 and DG with decrease in thickness of neuronal cells in all regions. These changes were aggravated and more 


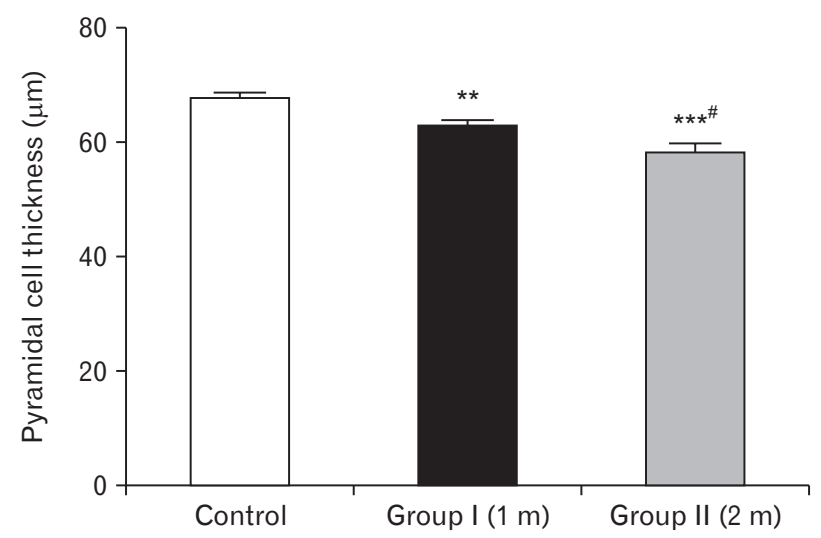

Fig. 23. A bar chart showing pyramidal cell thickness (in $\mu \mathrm{m}$ ) among the three groups. Pyramidal cells' thickness is highly significantly reduced in one-month group and two-months group respectively compared to the control group $\left({ }^{* *} P<0.01,{ }^{* *} P<0.001\right)$, and significant reduction was observed in two-months group compared to one-month group $\left({ }^{\#} P<0.05\right)$.

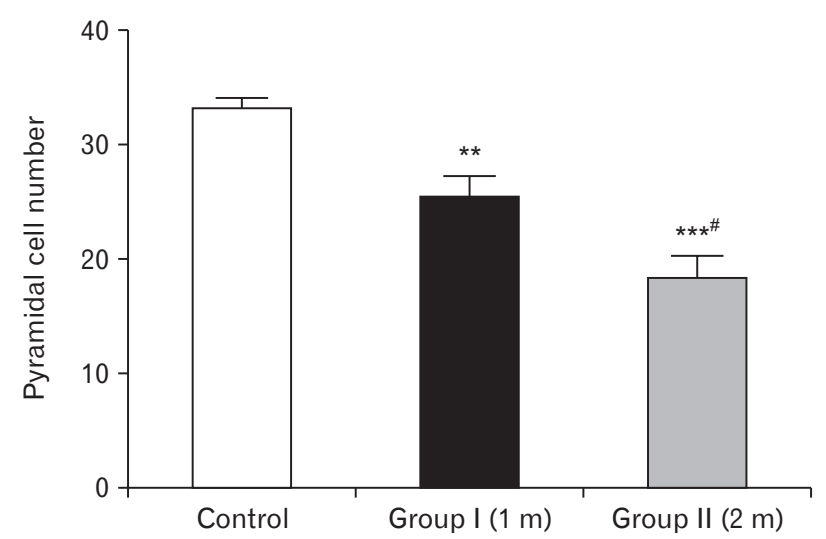

Fig. 24. A bar chart showing pyramidal cell number among the three groups. Pyramidal cells' number are highly significantly reduced in one-month group and two-months group respectively compared to the control group $\left({ }^{* *} P<0.01,{ }^{* *} P<0.001\right)$, with more significant decreased number in the two-months group than one-month group $\left({ }^{*} P<0.05\right)$.

prominent after another month of administration. This was supported by some studies that observed the adverse effects of Red Bull ingredients on the brain with many nervous manifestations $[14,15]$ and mood changes $[16,17]$.

Histopathological examination observed degenerated neuronal cells with dark nuclei, increased pericellular space and multiple ghost cells after one month of Red Bull administration. Pyramidal cells' thickness and number were statistically highly significant reduced after one and two months of Red Bull administration respectively compared to the control group. These degenerative findings were markedly increased after two-month duration compared to one-

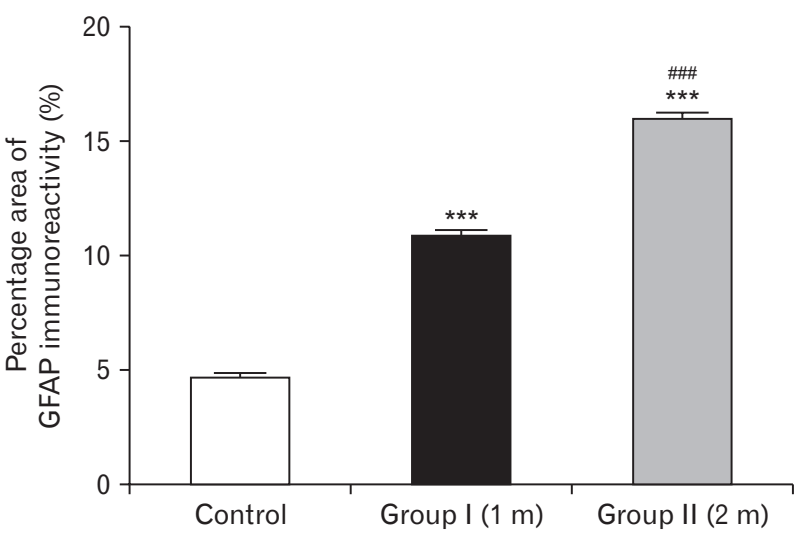

Fig. 25. A bar chart showing the percentage area of GFAP immunoreactivity in the three groups. The area is highly significantly increased in one-month group and two-months group respectively compared to the control group $\left({ }^{* * *} P<0.001\right)$, with more significant increase in the two-months group than in one-month $\left({ }^{\# \#} P<0.001\right)$. GFAP, glial fibrillary acidic protein.

month duration. In addition, after two-month administration of Red Bull, signet ring cells appeared with pyknotic peripheral nuclei. This was in accordance with Bawazirand and Almehmadi [32] who also observed degeneration of nerve cells, apoptosis of large pyramidal cells, necrosis of the nervous tissue in the hippocampus of rats after three weeks of daily administration of Red Bull. These changes could be attributed to the deleterious effect of caffeine; the main constituent of energy drinks [33]. Blaise et al. [34], described that caffeine disrupts the synaptic plasticity in hippocampal neurons through inhibition of long-term potentiation at the synapse. Huang et al. [35] and Lazarus et al. [36] added that chronic caffeine consumption decreased long term potentiation, by disrupting the normal sleep-waking cycle. Another study declared that consumption of caffeine could inhibit hippocampus-dependent learning and memory partially through inhibition of hippocampal neurogenesis [37].

In addition to the neuronal cell loss immediately after treatment with caffeine and taurine, a significant reduction in number and length of total dendrites mainly caused by a reduction of higher dendrite branching was observed [38]. Furthermore, disturbed maintenance and disruption of dendrites and synapses has been associated with psychiatric illnesses, such as schizophrenia and major depressive disorders, as well as neurodegenerative diseases, such as Alzheimer's disease (AD) [39]. Abo El-Khair et al. [40] also observed similar findings as disarrangement and shrinkage of pyramidal cells with decrease in their dendritic arborization and spine numbers as a direct result of aging process. 
Recent studies have suggested that consumption of energy drinks alone or combined with alcohol leads to oxidative stress and inflammatory response in the brain [41-43]. Components of energy drinks as caffeine, taurine, and guarana were reported to reduce basal-free radical generation as superoxide dismutase and catalase in vitro [44]. The mitochondria represent the 'hot-spot' for degenerative processes. Both oxidative stress and excessive production of reactive oxygen species produce an abnormal activity of the mitochondrial complex I, which directly interferes with cellular adenosine triphosphate production, causing neuronal cell death [45].

Beside mitochondrial dysfunction, other postulated underlying molecular mechanisms for neuronal cell death include glutamate-related excitotoxicity, the formation of advanced glycation end products and the possible inhibition of Nuclear factor (erythroid-derived 2)-like 2 that is closely related to anti-inflammation and oxidative stress [46].

In the current work, GFAP stained sections showed increased immunoreactivity with energy drinks administrated groups in the form of an apparent increased distribution of star shaped astrocytes indicating reactive astrocytosis. These findings were supported by statistical analysis. The area percentage of GFAP immuno-reactivity was statistically highly significant in the one- and two-months experimental groups respectively compared to the control group with more significant increase after two months compared to one-month group. Vallés et al. [47] and Kang et al. [48] explained that the inflammatory response of the brain by reactive astrocytosis and production of various inflammatory mediators, leads to neuronal death. Díaz et al. [41] added that daily intake of energy drinks causes neuronal inflammation and on chronic use it can cause neuronal death.

Reactive astrocytes gain neurotoxic properties as they secrete lipocalin 2, which is a potent neurotoxic mediator [49]. Also, abnormal regulation of calcium and glutamate homeostasis in reactive astrocytes may lead to the neurodegeneration. In hippocampus of AD mice, excessive GABA released by reactive astrocytes results in tonic inhibition of DG granule cells [50].

Moreover, in the present study, examining DG of group II revealed lightly stained ghost cells with some dark stained cells, while that of group III revealed apparent thinning of granule cell layer, with widespread cracks within the layer. Most of the cells appeared with dark pyknotic nuclei, some signet ring neurons, intense vacuolations and cracks in between the cells were observed. This was supported by Spans- wick and Sutherland [51], who declared that after 10-week of hippocampal degeneration, an approximate $50 \%$ reduction of neurons within the granule cell layer of the DG was observed.

Also, an increased number of stem cells within the crest of DG were recorded in the present work. This was explained by Gebril et al. [52] who observed an increase in the proliferation of stem cells in the DG following brain injury.

In conclusion, the current study revealed the degenerative effects of energy drinks as Red Bull on the histological structure of hippocampal CA1 and DG of the adult male albino rats. These degrative effects were directly related to the duration of intake of such drinks.

\section{ORCID}

Sherif A. Kamar: https://orcid.org/0000-0002-3682-869X

Hany W. Abdel Malak:

https://orcid.org/0000-0003-2490-6555

Shereen Adel Saad:

https://orcid.org/0000-0002-8863-7553

\section{Author Contributions}

Conceptualization: SAK, HWAM, SAS. Data acquisition: SAK, HWAM, SAS. Data analysis or interpretation: SAK, HWAM, SAS. Drafting of the manuscript: SAK, HWAM, SAS. Critical revision of the manuscript: HWAM. Approval of the final version of the manuscript: all authors.

\section{Conflicts of Interest}

No potential conflict of interest relevant to this article was reported.

\section{References}

1. Seifert SM, Schaechter JL, Hershorin ER, Lipshultz SE. Health effects of energy drinks on children, adolescents, and young adults. Pediatrics 2011;127:511-28.

2. Backer WS, Baeissa HM. Effect of different energy drinks on liver and heart enzymes in rats. Int J Biotechnol 2014;3:1-11.

3. Mubarak R. Effect of Red Bull energy drink on rats' submandibular salivary glands (light and electron microscopic study). J Am Sci 2012;8:366-72.

4. Abian P, Del Coso J, Salinero JJ, Gallo-Salazar C, Areces F, Ruiz-Vicente D, Lara B, Soriano L, Muñoz V, Abian-Vicen J. 
The ingestion of a caffeinated energy drink improves jump performance and activity patterns in elite badminton players. J Sports Sci 2015;33:1042-50.

5. Prins PJ, Goss FL, Nagle EF, Beals K, Robertson RJ, Lovalekar MT, Welton GL. Energy drinks improve five-kilometer running performance in recreational endurance runners. J Strength Cond Res 2016;30:2979-90.

6. Campbell B, Wilborn C, La Bounty P, Taylor L, Nelson MT, Greenwood M, Ziegenfuss TN, Lopez HL, Hoffman JR, Stout JR, Schmitz S, Collins R, Kalman DS, Antonio J, Kreider RB. International Society of Sports Nutrition position stand: energy drinks. J Int Soc Sports Nutr 2013;10:1.

7. Clauson KA, Shields KM, McQueen CE, Persad N. Safety issues associated with commercially available energy drinks. J Am Pharm Assoc (2003) 2008;48:e55-63; quiz e64-7.

8. Vivekanandarajah A, Ni S, Waked A. Acute hepatitis in a woman following excessive ingestion of an energy drink: a case report. J Med Case Rep 2011;5:227.

9. Attila S, Cakir B. Energy-drink consumption in college students and associated factors. Nutrition 2011;27:316-22.

10. Grasser EK, Miles-Chan JL, Charrière N, Loonam CR, Dulloo AG, Montani JP. Energy drinks and their impact on the cardiovascular system: potential mechanisms. Adv Nutr 2016;7:95060 .

11. Bukhar HM, ElSawy NA, Header EA. Biological effect of high energy drink on normal and hyperglycemic rats. Pakistan J Nutr 2012;11:301-9.

12. Worthley MI, Prabhu A, De Sciscio P, Schultz C, Sanders P, Willoughby SR. Detrimental effects of energy drink consumption on platelet and endothelial function. Am J Med 2010;123:184-7.

13. Ebuehi OA, Ajayl OE, Onyeulor AL, Awelimobor D. Effects of oral administration of energy drinks on blood chemistry, tissue histology and brain acetylcholine in rabbits. Nig Q J Hosp Med 2011;21:29-34.

14. Guilbeau JR. Health risks of energy drinks: what nurses and consumers need to know. Nurs Womens Health 2012;16:423-8.

15. Buck R, Dixon J, Matjasich L, Petersen R. Energy drink consumption among adolescents and young adults: health effects and implications for practice. Salt Lake City: Westminster College; 2013. 58 P.

16. Tibrewal P, Dhillon R. Caffeine induced psychotic exacerbation. Aust N Z J Psychiatry 2011;45:179-80.

17. Ishak WW, Ugochukwu C, Bagot K, Khalili D, Zaky C. Energy drinks: psychological effects and impact on well-being and quality of life-a literature review. Innov Clin Neurosci 2012;9:25-34.

18. Andersen P, Morris R, Amaral D, Bliss T, O’Keefe J. The hippocampus book. New York: Oxford University Press; 2007.

19. Mesulam MM. Behavioral neuroanatomy: large-scale networks, association cortex, frontal syndromes, the limbic system, and the hemispheric specializations. In: Mesulam MM, editor. Principles of behavioral and cognitive neurology. 2nd ed. New York: Oxford University Press; 2000. P. 1-120.
20. Malinauskas BM, Aeby VG, Overton RF, Carpenter-Aeby T, Barber-Heidal K. A survey of energy drink consumption patterns among college students. Nutr J 2007;6:35.

21. Hashish HA. Histopathologic effect of prenatal topiramate exposure on rat cerebral cortex and hippocampus. J Interdiscipl Histopathol 2014;2:61-8.

22. Huang TT, Zou Y, Corniola R. Oxidative stress and adult neurogenesis--effects of radiation and superoxide dismutase deficiency. Semin Cell Dev Biol 2012;23:738-44.

23. Licht T, Kreisel T, Biala Y, Mohan S, Yaari Y, Anisimov A, Alitalo K, Keshet E. Age-dependent remarkable regenerative potential of the dentate gyrus provided by intrinsic stem cells. J Neurosci 2020;40:974-95.

24. Kassab AA, Tawfik SM. Effect of a caffeinated energy drink and its withdrawal on the submandibular salivary gland of adult male albino rats: a histological and immunohistochemical study. Egypt J Histol 2018;41:11-26.

25. Hamshari RGM. A study of the effect of khat on the offsprings of rabbits with special emphasis on its effect on the brain [Masters thesis]. Cairo: Faculty of Medicine Ain Shams University; 2006.

26. Bancroft JD, Gamble M. Theory and practice of histological techniques. 5th ed. London: Churchill Livingstone; 2002.

27. Graham L, Orenstein JM. Processing tissue and cells for transmission electron microscopy in diagnostic pathology and research. Nat Protoc 2007;2:2439-50.

28. Mahdy AA. Possible protective effect of ascorbic acid and alpha-tocopherol against damage induced by ionizing radiation in adult albino rat hippocampus. Egypt J Anat 2014;37:301-21.

29. Gao Y, Bezchlibnyk YB, Sun X, Wang JF, McEwen BS, Young LT. Effects of restraint stress on the expression of proteins involved in synaptic vesicle exocytosis in the hippocampus. Neuroscience 2006;141:1139-48.

30. Sawilowsky SS. Misconceptions leading to choosing the t test over the Wilcoxon Mann-Whitney test for shift in location parameter. J Mod Appl Stat Methods 2005;4:598-600.

31. Frane AV. Are per-family Type I error rates relevant in social and behavioral science? J Mod Appl Stat Methods 2015;14:1223.

32. Bawazirand AE, Almehmadi MG. Effect of "Red Bull" energy drink on some neurotransmitters content and histological structure of cerebral cortex in male albino rats. Life Sci J 2017;14:63-73.

33. Akande IS, Banjoko OA. Assessment of biochemical effect of "Power Horse" energy drink on hepatic, renal and histological functions in Sprague Dawley rats. Annu Res Rev Biol 2011;1:4556.

34. Blaise JH, Park JE, Bellas NJ, Gitchell TM, Phan V. Caffeine consumption disrupts hippocampal long-term potentiation in freely behaving rats. Physiol Rep 2018;6:e13632.

35. Huang ZL, Qu WM, Eguchi N, Chen JF, Schwarzschild MA, Fredholm BB, Urade Y, Hayaishi O. Adenosine A2A, but not A1, receptors mediate the arousal effect of caffeine. Nat Neurosci 2005;8:858-9. 
36. Lazarus M, Shen HY, Cherasse Y, Qu WM, Huang ZL, Bass CE, Winsky-Sommerer R, Semba K, Fredholm BB, Boison D, Hayaishi O, Urade Y, Chen JF. Arousal effect of caffeine depends on adenosine A2A receptors in the shell of the nucleus accumbens. J Neurosci 2011;31:10067-75.

37. Han ME, Park KH, Baek SY, Kim BS, Kim JB, Kim HJ, Oh SO. Inhibitory effects of caffeine on hippocampal neurogenesis and function. Biochem Biophys Res Commun 2007;356:976-80.

38. Arikkath J. Molecular mechanisms of dendrite morphogenesis. Front Cell Neurosci 2012;6:61.

39. Lin YC, Koleske AJ. Mechanisms of synapse and dendrite maintenance and their disruption in psychiatric and neurodegenerative disorders. Annu Rev Neurosci 2010;33:349-78.

40. Abo El-Khair DM, El-Safti Fel-N, Nooh HZ, El-Mehi AE. A comparative study on the effect of high cholesterol diet on the hippocampal CA1 area of adult and aged rats. Anat Cell Biol 2014;47:117-26.

41. Díaz A, Treviño S, Guevara J, Muñoz-Arenas G, Brambila E, Espinosa B, Moreno-Rodríguez A, Lopez-Lopez G, Peña-Rosas U, Venegas B, Handal-Silva A, Morán-Perales JL, Flores G, Aguilar-Alonso P. Energy drink administration in combination with alcohol causes an inflammatory response and oxidative stress in the hippocampus and temporal cortex of rats. Oxid Med Cell Longev 2016;2016:8725354.

42. Al-Shaar L, Vercammen K, Lu C, Richardson S, Tamez M, Mattei J. Health effects and public health concerns of energy drink consumption in the United States: a mini-review. Front Public Health 2017;5:225.

43. Al-Basher GI, Aljabal H, Almeer RS, Allam AA, Mahmoud AM. Perinatal exposure to energy drink induces oxidative damage in the liver, kidney and brain, and behavioral alterations in mice offspring. Biomed Pharmacother 2018;102:798811.
44. Zeidán-Chuliá F, Gelain DP, Kolling EA, Rybarczyk-Filho JL, Ambrosi P, Terra SR, Pires AS, da Rocha JB, Behr GA, Moreira JC. Major components of energy drinks (caffeine, taurine, and guarana) exert cytotoxic effects on human neuronal SH-SY5Y cells by decreasing reactive oxygen species production. Oxid Med Cell Longev 2013;2013:791795.

45. Maiti P, Manna J, Dunbar GL. Current understanding of the molecular mechanisms in Parkinson's disease: targets for potential treatments. Transl Neurodegener 2017;6:28.

46. Li Q, Xing S, Chen Y, Liao Q, Li Q, Liu Y, He S, Feng F, Chen Y, Zhang J, Liu W, Guo Q, Sun Y, Sun H. Reasonably activating Nrf2: a long-term, effective and controllable strategy for neurodegenerative diseases. Eur J Med Chem 2020;185:111862.

47. Vallés SL, Blanco AM, Pascual M, Guerri C. Chronic ethanol treatment enhances inflammatory mediators and cell death in the brain and in astrocytes. Brain Pathol 2004;14:365-71.

48. Kang SH, Lee YA, Won SJ, Rhee KH, Gwag BJ. Caffeineinduced neuronal death in neonatal rat brain and cortical cell cultures. Neuroreport 2002;13:1945-50.

49. Bi F, Huang C, Tong J, Qiu G, Huang B, Wu Q, Li F, Xu Z, Bowser R, Xia XG, Zhou H. Reactive astrocytes secrete lcn 2 to promote neuron death. Proc Natl Acad Sci U S A 2013;110:4069-74.

50. Li K, Li J, Zheng J, Qin S. Reactive astrocytes in neurodegenerative diseases. Aging Dis 2019;10:664-75.

51. Spanswick SC, Sutherland RJ. Object/context-specific memory deficits associated with loss of hippocampal granule cells after adrenalectomy in rats. Learn Mem 2010;17:241-5.

52. Gebril HM, Rose RM, Gesese R, Emond MP, Huo Y, Aronica E, Boison D. Adenosine kinase inhibition promotes proliferation of neural stem cells after traumatic brain injury. Brain Commun 2020;2:fcaa017. 